\title{
Another Bridge to Cross
}

Lori Gruen

University of Colorado

A review of Carol Adams' The Sexual Politics of Meat (New York: Continuum, 1990)

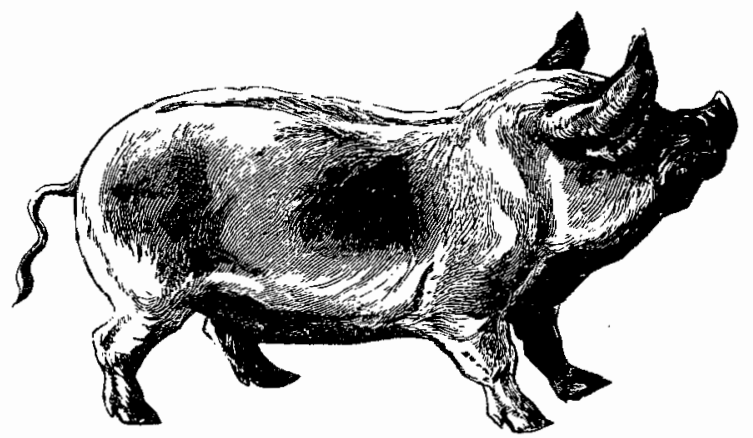

"It is not possible now, and never will be, to say I renounce. Nor would it be a good thing for literature were it possible...."

In choosing this quote, from Virginia Woolf, to begin The Sexual Politics of Meat: A Feminist-Vegetarian Critical Theory, Carol Adams appropriately highlights certain central characteristics of contemporary feminist thought and thus locates her own work firmly in the tradition of feminist theorizing. By pointing out the impossibility and lack of desirability in renunciation, Adams through Woolf points to self-reclamation as opposed to self-denial as a tool for social change. Renunciation has for centuries been the defining characteristic of women: a good woman sacrifices and serves. The compulsory institutions of marriage and motherhood (and as Adams will argue, meat-eating) are just a few examples of how this renunciation is enforced.

I point out these somewhat subtle implications of the opening quotation because I think they are important in understanding Adams' project. Her work is not, on my reading, intended to be a call for renunciation, guilt-tripping, or brow-beating but, rather, is about recognizing connections and building

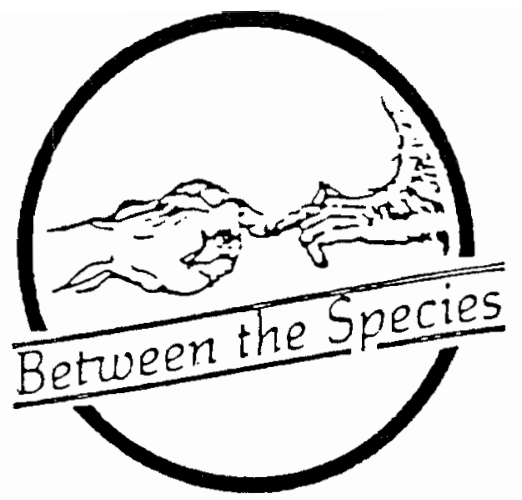

bridges. Many people sympathetic to vegetarianism may not read the book because they have misconceptions about feminist renunciation; misconceptions that have recently been promoted by media portrayals of "feminazis" who have moved beyond bra-burning to male-bashing and the imposition of political correctness. ${ }^{1}$ Similarly, many feminists may shrug the book off because of certain misconceptions they may have about vegetarian renunciation and a vegetarian lifestyle, often seeing it as yet another way of denying women freedom of choice. ${ }^{2}$ These misconceptions are part of a problem for which The Sexual Politics of Meat presents some solutions. As Adams writes, "I see the oppression of women and the other animals as interdependent," $(16)$ and thus believes ending the oppression of one is connected to ending the oppression of the other. The Sexual Politics of Meat is therefore crucial reading for vegetarians and feminists alike.

When the book first came out in 1990, it was my hope that it would serve to bring feminists and animal liberationists closer together. This hasn't really happened. While such a grand social phenomenon seldom occurs as the result of one book, I do think at least part of the reason such coalitions did not form has something to do with the way the book was written. The language of literary criticism that Adams adopts often leads to problems with clarity which in turn causes

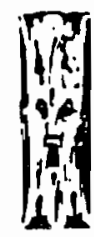

REVIEW 
the force of certain arguments to be lost and in some instances contributes to outright confusion.

The Sexual Politics of Meat is largely about words, texts, and history, topics that, rightly or wrongly, do not usually occupy the minds of most social activists, who tend to focus more on the material conditions that cause immediate suffering. In Part One, "The Patriarchal Texts of Meat," Adams examines words and metaphors and argues that "the cycle of objectification, fragmentation, and consumption...links butchering and sexual violence in our culture." In Part Two, "From the Belly of Zeus," she explores vegetarian literary texts and their relationship to feminist history, primarily focusing on Anglo-writers from 1790 to the present. In the final part, "Eat Rice Have Faith in Women," Adams examines how feminists have continued to reproduce patriarchal discourse by either unwittingly ignoring or intentionally silencing vegetarian words and bodies. In response, she calls for "feminist-vegetarian critical theory [which] begins with the perception that women and animals are similarly positioned in a patriarchal world, as objects rather than subjects." (168) and "feminist-vegetarian activity [which] declares that an alternative worldview exists, one which celebrates life rather than consuming death; one which does not rely on resurrected animals but empowered people." (185).

Despite my political concerns about the potential inaccessibility of the book for many feminists and vegetarians, The Sexual Politics of Meat does provide an important analysis of language and the power words have in shaping our conceptual frameworks. According to Adams, language reinforces oppression and she suggests we examine the language about meat eating as a way of understanding how these words provide cultural meanings which have historically served to justify the practice of animal slaughter and flesh consumption. For example, Adams points out "the choice of 'it' for meat [as] the final capitulation to the dominant reality that renders real animals invisible and masks violence" (64). "It" is a term for an inanimate, unfeeling object. When we refer to animals as "its," we deny them their subjectivity.

This denial is part of what Adams calls the "absent referent." Animals become absent referents in three ways: first, literally-"through meat eating they are literally absent because they are dead"; second, definitionally- "when we eat animals we change the way we talk about them," they are no longer pigs, for example, but pork; and third, metaphorically_in which "the meaning of the absent referent derives from its application or reference to something else," most commonly women's experiences of sexual harassment or assault (41-2).

I find Adams' discussion of the literal and definitional aspects of the absent referent particularly illuminating for understanding the process which allows humans to detach themselves from the animals they consume. Just as it is difficult for humans to slit the throats of the animals that will be dinner because of the direct and immediate impact of such actions, so too is it difficult to maintain psychological detachment from animals if we recognize their likenesses to us. The absent referent serves to make this detachment easier. By failing to take note of the distinctive characteristics of individual animals and conceptualizing them as a class (such as "meat," "pork" or "hamburger") which lacks the familiar characteristics that generate compassion and concern, humans are able to justify their indifference to the plight of individual animals. Recently, Adams has expanded her analysis of our use of language to include what she calls "False Mass Terms." She writes, "when we turn an animal into 'meat,' someone who has a very particular, situated life, a unique being, is converted into something that has no distinctiveness, no uniqueness, no individuality."3

The usefulness of Adams' discussion of the metaphorical understanding of the absent referent, however, may serve to obfuscate rather than clarify her thesis. Her purpose is to suggest that the metaphorical appropriation of "meat," particularly by women who have been raped or battered-women who often describe their experiences as "feeling like pieces of meat" - is problematic. Unfortunately, in her discussion, it is unclear how she herself understands the parallels between "the rape of animals and the butchering of women," and thus her critique is open to potential misinterpretation. After grappling with her discussion, I agree with Adams that women who are raped or battered and describe their experiences as feeling like meat have not made the connection between their own oppression and the oppression of animals. It is indeed unfortunate that feminist discussions of violence against women "take us to the intersection of the oppression of women and the oppression of animals and then do an immediate about face, seizing the function of the absent referent to forward women's issues and so imitating and complementing a patriarchal structure." (60) Had 
Adams' discussion of this very important point been clearer, I believe her conclusion could have been more forcefully received.

It is possible, however, that even if Adams was clearer about the metaphorical way the absent referent functions, her words would not have been received, much like the early feminist and vegetarian protest literature she discusses in the second part of the book. The vegetarian word has always come up against significant obstacles. It has been trivialized, made to look hysterical or extreme, or has been rendered invisible, as has feminist speech. As Adams writes in her discussion of the monster in Mary Shelley's Frankenstein, "like feminists, its speech was muted by the dominant social order, as is vegetarianism.... Vegetarian revelations, terse as they are, are silenced because we have no framework into which we can assimilate them...."(119) Feminist frameworks, Adams suggests, can become the lens through which vegetarian words and bodies become visible.

Re-siting feminist-vegetarian words is timely, since there is a new oppositional discourse emerging which has begun questioning whether feminists should be vegetarians. These contemporary discussions are mired in the manipulation tactics that obscured arguments for vegetarianism in the 18th and 19th centuries. Here the authority of dominant discourse is asserted under the guise of a narrative that is supposedly questioning tradition. Like recent defenses of all animal experimentation, discussions which reject feminist-vegetarianism are conducted apparently without the benefit of the discussants having read original texts. ${ }^{4}$ Whether one agrees or disagrees with feminist-vegetarianism, reading The Sexual Politics of Meat is important not only to understand Adams' text but because her reading of original texts locates feminist-vegetarianism in its cultural and historical context.

Though Adams is at times overly concerned with bodies of literature, she is not so caught up in language as to ignore the very real pain inflicted on the bodies of animals in the "meat" production industry. Unlike many literary critics who have gone so far as to suggest that reality is the text, Adams believes that the analysis of language and conceptual frameworks cannot be done in place of the material analysis that is crucial to ending such practices as factory farming. Indeed, according to her, one cannot and must not be done at the expense of the other.
The Sexual Politics of Meat makes connections between words and life.

The patriarchal structure of the absent referent that renders women and animals absent as subjects, collapses referent points, and results in overlapping oppression, requires a combined challenge by feminism and vegetarianism. Yet, this oppression of women and animals, though unified by the structure of the absent referent, is experienced separately and differently by women and animals. Thus, it is an oppressive structure that, when perceived, is often perceived in fragments and attacked in fragmented ways, i.e., some women work for their liberation, other women and men challenge the oppression of animals. (169).

By introducing such notions as the "absent referent" and thus providing new analyses of the ways in which the consumption of animals fits into and reinforces the oppressing structures of patriarchy, Adams has created a bridge over this fragmentation. It is now up to feminists and vegetarians, and everyone interested in living less destructive lives, to cross it.

\section{Notes}

${ }^{1}$ As Adams writes, this sort of dismissal is one that "preestablishes the perimeters of discourse. One must explain that no bras were burned at the Miss America pageant." (89) One is diverted from their main point by explaining that various items were symbolically burned in protest of the inferior social status of women, just as draft cards were burned at the same time in protest of the war in Vietnam. Similarly one is forced to explain that "political correctness" was a term feminists used to joke amongst themselves, one that has been appropriated by conservatives and critics of curriculum reform.

${ }^{2}$ This is an argument that many feminist organizations have used in response to suggestions that their conferences be crueltyfree and that only vegetartian or vegan food be served.

3 "The Traffic in Animals" in Greta Gard (ed.) Ecofeminism: Women, Animals, Nature (Philadelphia: Temple University Press, 1993) p. 201.

\footnotetext{
${ }^{4}$ I have argued elsewhere that this tactic, particularly as it is used by supporters of animal experimentation, does nothing to forward reasoned discussion. See M. Bekoff, L. Gruen, et. al. "Animals in Science: Some Areas
} 
Revisited," Animal Behaviour 44. For an example of this trend amongst so-called feminist work, see Kathryn Paxton George "So Human an Animal..., or the Moral Relevance of Being an Omnivore," The Journal of Agricultural Ethics 3:2 (1990) and "Should Feminists be Vegetarians?" Signs (forthcoming). Though she cites Adams' work in the latter paper, she doesn't actually engage with the growing ecofeminist literature in this area.

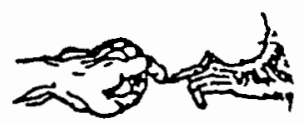

\section{Behold,Thou Art Fair, My Beloved:}

Green is the colour of sacred.

Cathedral forests

And the Coming of spring.

Blue

Is the colour of Mystery,

Of Earth,

Swaddled in gauze white sky.

White is the glacial virgin ice

Of untouched places.

Yellow,

The heat of life,

Of summer's passion

And the urgency of love.

Silver the salmon

Running the river for home

In the soft pearl mist of dawn.

Scarlet, the bird of Paradise,

The Word made flesh.

Indigo black panther,

The flesh transformed.

A rainbow creation,

A planet of many colours,

Shining softly

In a State of Grace.

Mary de La Valette

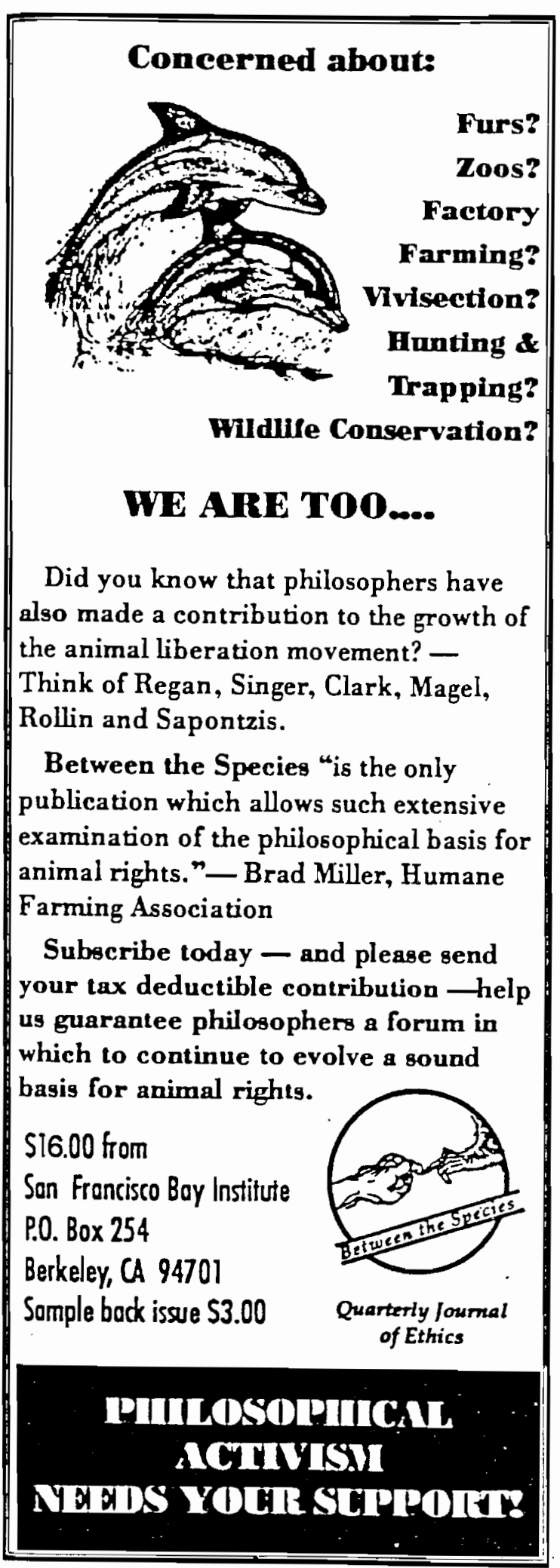

